\title{
Modifikasi Biosand Filter Pasir Gumuk Sebagai Upaya Pengelolaan Air Sungai Gadjahwong Yogyakarta
}

\author{
Ardyan Pramudya Kurniawan,", ${ }^{1,}$ Maizer Said Nahdi ${ }^{1}$, Siti Aisah ${ }^{1}$ \\ ${ }^{1}$ Laboratorium Ekologi Fakultas Sains dan Teknologi UIN Sunan Kalijaga \\ Email korespondensi : ardyan.kurniawan@uin-suka.ac.id
}

\begin{abstract}
Abstrak
Air memiliki peranan penting bagi manusia, untuk keperluan sehari - hari (minum, mandi, memasak, pertanian, peternakan, dan mencuci). Bertambahnya jumlah penduduk Yogyakarta setiap tahun, menyebabkan meningkatnya kebutuhan air bersih. Sumber air dapat diperoleh dari air laut, mata air, danau dan air sungai. Penelitian ini bertujuan untuk mengolah air sungai Gadjahwong menjadi air bersih, dengan menggunakan biosand filter pasir gumuk. Metode yang digunakan dalam penelitian ini, yaitu dengan melakukan pengujian parameter fisik, kimia dan biologi di Laboratorium Kimia Terpadu Universitas Islam Indonesia. Berdasarkah hasil penelitian terjadi penurunan nilai residu tersuspensi (TSS) $67 \mathrm{mg} / \mathrm{L}$ menjadi 21,5 mg/L, dan menurunkan turbiditas (kekeruhan) dari 9,12 NTU menjadi 0,88 NTU. Sedangkan secara kimiawi dapat meningkatkan nilai dissolved oxygen (DO) dari 4,37 mg/L menjadi $5 \mathrm{mg} / \mathrm{L}$; menurunkan kadar Klorida (Cl-) dalam perairan dari $14,1 \mathrm{mg} / \mathrm{L}$ menjadi $4 \mathrm{mg} / \mathrm{L}$; dan menurunkan kadar detergen $0,28 \mathrm{mg} / \mathrm{L}$ menjadi $0,14 \mathrm{mg} / \mathrm{L}$. Dari penelitian tersebut disimpulkan bahwa modifikasi biosand filter menggunakan pasir gumuk dapat meningkatkan kualitas perairan secara fisik dan kimiawi.
\end{abstract}

Kata Kunci: Biosand filter, Pasir Gumuk, Sungai Gadjahwong, reverse osmosis

\begin{abstract}
Water has an important role for humans for daily needs, i.e., drinking, bathing, cooking, agriculture, animal husbandry, and washing. In addition, the increasing number of residents of Yogyakarta every year causes an increase in the need for clean water demand. Water sources can be obtained from seawater, springs, lakes, and river water. This study aims to treat the water of the Gadjahwong river into clean water by using a dune bio-sand filter. The method used in this study, namely by testing physical, chemical, and biological parameters at the Integrated Chemistry Laboratory, Islamic University of Indonesia. Based on the study results, there was a decrease in the suspended residue value (TSS) from $67 \mathrm{mg} / \mathrm{L}$ to $21.5 \mathrm{mg} / \mathrm{L}$ and decreased turbidity (turbidity) from 9.12 NTU to 0.88 NTU. Meanwhile, chemically it can increase the dissolved oxygen (DO) value from 4.37 $\mathrm{mg} / \mathrm{L}$ to $5 \mathrm{mg} / \mathrm{L}$; decrease Chloride $(\mathrm{Cl}-)$ in the waters from $14.1 \mathrm{mg} / \mathrm{L}$ to $4 \mathrm{mg} / \mathrm{L}$, and reduce detergent levels from $0.28 \mathrm{mg} / \mathrm{L}$ to $0.14 \mathrm{mg} / \mathrm{L}$. This research concluded that modification of sand filter using dune sand could improve water quality physically and chemically.
\end{abstract}

Keywords: Biosand filter, Pasir Gumuk, Gadjahwong River, reverse osmosis

\section{PENDAHULUAN}

Air memiliki peranan penting bagi manusia, untuk keperluan sehari - hari (minum, mandi, memasak, pertanian, peternakan, dan mencuci). Menurut McGhee dan Steel (1991), tingkat penggunaan air untuk kebutuhan domestik ini bervariasi tergantung dari tingkat ekonomi tiap-tiap rumah tangga, umumnya antara $75-380$ L/orang/hari. Badan Pusat Statistik (BPS) Yogyakarta menyebutkan bahwa jumlah penduduk Yogyakarta tahun 2020 sebesar 3,6 juta jiwa, sehingga dalam satu hari dibutuhkan air bersih kurang lebih $270-1.368$ juta liter. Bertambahnya jumlah penduduk Yogyakarta setiap tahun, menyebabkan meningkatnya kebutuhan air bersih. Sumber air dapat diperoleh dari air laut, mata air, danau dan air sungai, tetapi hanya 3\% dari sumber tersebut yang dapat dikonsumsi oleh manusia (Suripin, 2001). Salah satu sumber air alternatif di kota Yogyakarta yang dapat digunakan bersumber dari Sungai Gadjahwong. Akan tetapi sumber yang berasal dari Sungai Gadjahwong, belum dilakukan pengolahan. Sehingga air sungai tersebut mengandung limbah domestik berbahan organik (protein, karbohidrat, dan lemak) dan anorganik (garam dan metal) yang terlarut maupun tersuspensi (Kodoatie et.al., 2010). 
Belum adanya pengelolaan limbah yang dibuang ke Sungai Gadjahwong dapat menyebabkan terjadinya penuruan kualitas air dan tanah, merusak ekosistem perairan sungai, menimbulkan bau, dan penurunan estetika suatu wilayah (Samina et.al., 2013; Nurhayati et.al., 2019). Oleh karena itu untuk mengolah air sungai yang terpapar oleh limbah domestik diperlukan suatu teknologi alternatif, yaitu dengan menggunakan Biosand filter. Berdasarkan penelitian yang dilakukan oleh Endarko et al., (2013), proses sterilisasi air sungai di Surabaya dengan menggunakan metode biosand filter dan lampu ultraviolet mampu menghasilkan air bersih dan air minum.

Dalam Peraturan Gubernur Daerah Istimewa Yogyakarta Nomor 20 Tahun 2008, tentang Baku Mutu Air dinyatakan bahwa perlu adanya pemantauan dan pengawasan terhadap mutu air. Usaha yang dilakukan untuk meningkatkan mutu air, adalah dengan cara pencegahan dan penanggulangan pencemaran air. Salah satu cara yang dilakukan, yaitu dengan mengolah air limbah sebelum air limbah tersebut masuk ke sungai, atau melakukan pengolahan air sungai yang sudah tercemar. Oleh karena itu penelitian ini bertujuan untuk mengolah air sungai Gadjahwong menjadi air bersih, dengan menggunakan biosand filter pasir gumuk.

\section{BAHAN DAN METODE}

Penelitian dilaksanakan pada bulan Oktober - Desember 2016 di laboratorium ekologi UIN Sunan Kalijaga. Metode yang digunakan dalam penelitian ini adalah mengolah air sungai menjadi air bersih sesuai dengan nilai baku mutu air kelas I (Pergub DIY Nomor 20 Tahun 2008). Pada penelitian ini dibagi menjadi dua bagian, yaitu 1) pembuatan rancang bangun reaktor biosand filter pasir gumuk untuk proses penjernihan air sungai menjadi air bersih (Gambar 1); dan 2) Penelitian laboratorium dengan melakukan pemeriksaan sampel air.

Sampel air yang diukur adalah sampel air sungai yang terdapat pada bak penampung dan sampel air yang keluar dari sistem modifikasi biosand filter. Pengambilan sampel air dilakukan sebanyak masing- masing satu kali pengukuran. Parameter air yang diuji pada penelitian ini meliputi parameter fisik (TSS, TDS, tingkat kekeruhan, dan konduktivitas); kimia (pH air, DO, BOD, COD, Besi, Seng, Klorida, Nitrit, Sulfat, minyak lemak dan detergen); dan Mikrobiologis (total coliform dan Esserchia coli).

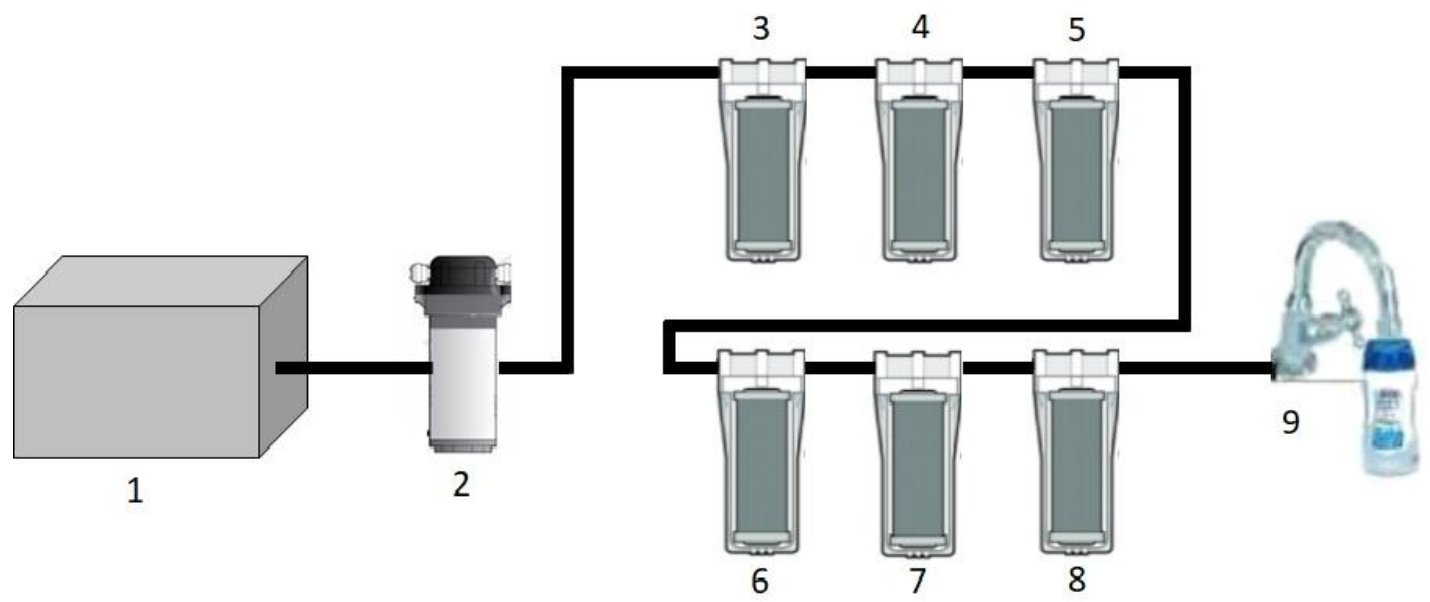

Gambar 1. Rancang bangun reaktor biosand filter pasir gumuk. 1) bak penampung air sungai yang ditambahkan eceng gondok; 2) pompa high pressure; 3) pasir gumuk; 4) pasir aktif; 5) karbon aktif; 6) pasir silika; 7) mangase; 8) zeolite; dan 9) faucet 


\section{HASIL DAN PEMBAHASAN}

Berdasarkan hasil pengujian sampel air Sungai Gadjahwong terdapat delapan parameter yang memiliki nilai melebihi nilai baku mutu air kelas I sesuai dengan Pergub DIY Nomor 20 Tahun 2008. Parameter tersebut yaitu TDS (166 mg/L), TSS (67 $\mathrm{mg} / \mathrm{L})$, tingkat kekeruhan $(9,12$ NTU), konsetrasi BOD (78,1 mg/L), COD (217 $\mathrm{mg} / \mathrm{L})$, detergen $(0,28 \mathrm{mg} / \mathrm{L})$, total Coliform $\left(15 \times 10^{3} \mathrm{MPN} / 100 \mathrm{~mL}\right)$, dan Esserchia coli $\left(4 \times 10^{3}\right.$ MPN/100mL) (Tabel 1). Sedangkan parameter yang memenuhi baku mutu air kelas I terdapat enam parameter, yaitu $\mathrm{pH}$ air $(6,5)$, Besi (Fe) $(<0,06 \mathrm{mg} / \mathrm{L})$, Seng ( $\mathrm{Zn}) \quad(<0,02$ $\mathrm{mg} / \mathrm{L})$, Klorida $\left(\mathrm{Cl}^{-}\right)(14,1 \mathrm{mg} / \mathrm{L})$, Nitrit $\left(\mathrm{NO}_{2}{ }^{-}\right)$ $(0,01 \mathrm{mg} / \mathrm{L})$, dan Sulfat $\left(\mathrm{SO}_{4}\right)(20,6 \mathrm{mg} / \mathrm{L})$ (Tabel 1).

Tabel 1. Hasil pengukuran kualitas air pada Sungai Gadjah Wong, sebelum dilakukan treatment dan sesudah dilakukan treatment modifikasi Biosand Filter menggunakan pasir gumuk.

Parameter

$\begin{array}{cc}\text { Sungai } & \text { Perlakuan Pasir } \\ \text { Gadjahwong } & \text { Gumuk }\end{array}$

PERGUB DIY No

20 Th 2008

(Baku Mutu Air

Kelas I)

\begin{tabular}{|c|c|c|c|}
\hline \multicolumn{4}{|l|}{ A. Fisik } \\
\hline Residu Terlarut/TDS ( (mg/L) & 166 & 187 & 1000 \\
\hline Residu Tersuspensi/TSS (mg/L) & 67 & 21,5 & 50 \\
\hline Kekeruhan (NTU) & 9,12 & 0,88 & 5 \\
\hline Konduktivitas $(\mu \mathrm{mhos} / \mathrm{cm})$ & 0,25 & 0,28 & \\
\hline \multicolumn{4}{|l|}{ B. Parameter Kimia } \\
\hline pH Air & 6,5 & 6,7 & $6-8,5$ \\
\hline $\mathrm{BOD}(\mathrm{mg} / \mathrm{L})$ & 78,1 & 87,4 & 2 \\
\hline $\mathrm{COD}(\mathrm{mg} / \mathrm{L})$ & 217 & 317 & 10 \\
\hline $\mathrm{DO}(\mathrm{mg} / \mathrm{L})$ & 4,37 & 5 & 6 \\
\hline $\operatorname{Besi}(\mathrm{Fe})(\mathrm{mg} / \mathrm{L})$ & $<0,06$ & $<0,06$ & 0,3 \\
\hline Seng $(\mathrm{Zn})(\mathrm{mg} / \mathrm{L})$ & $<0,02$ & $<0,02$ & 0,05 \\
\hline Klorida $\left(\mathrm{Cl}^{-}\right)(\mathrm{mg} / \mathrm{L})$ & 14,1 & 4 & 600 \\
\hline Nitrit $\left(\mathrm{NO}_{2}^{-}\right)(\mathrm{mg} / \mathrm{L})$ & 0,01 & $<0,01$ & 0,06 \\
\hline Sulfat $\left(\mathrm{SO}_{4}\right)(\mathrm{mg} / \mathrm{L})$ & 20,6 & 26,3 & 400 \\
\hline \multicolumn{4}{|l|}{ C. Parameter Kimia Organik } \\
\hline Minyak Lemak (mg/L) & $<14$ & $<14$ & 1 \\
\hline Detergen $(\mathrm{mg} / \mathrm{L})$ & 0,28 & 0,14 & 0.2 \\
\hline \multicolumn{4}{|l|}{ D. Mikrobiologi } \\
\hline Total Coliform (MPN/100mL) & $15 \times 10^{3}$ & $21 \times 10^{3}$ & $1 \times 10^{3}$ \\
\hline Esserchia coli (MPN/100mL) & $4 \times 10^{3}$ & $7 \times 10^{3}$ & 0 \\
\hline
\end{tabular}

\begin{abstract}
Menurut Suhartana (2006) air dikatakan keruh, apabila air tersebut mengandung partikel materi organic dan anorganik yang tersuspensi sehingga menyebabkan air berwarna. Kualitas air yang baik adalah jenih (bening) dan tidak keruh. Batas maksimal kekeruhan air kelas I menurut Pergub DIY nomor 20 tahun 2008, adalah 5 skala NTU. Dari hasil penelitian menunjukkan bahwa sampel air sungai Gadjahwong memiliki tingkat kekeruhan yang melebihi nilai baku mutu air dengan tingkat kekeruhan 9.12 NTU. Setelah dilakukan penyaringan menggunakan reaktor biosand filter menga-
\end{abstract}

lami penurunan tingkat kekeruhan 0.88 NTU. Sedangkan untuk konsentrasi TSS sebelum penyaringan menggunakan reaktor biosand filter sebesar $67 \mathrm{mg} / \mathrm{L}$ yang nilainya melebihi nilai baku mutu air $50 \mathrm{mg} / \mathrm{L}$. Setelah dilakukan penyaringan mengalami penurunan $21.5 \mathrm{mg} / \mathrm{L}$ (Tabel 1). Tingginya konsentrasi TSS sebelum penyaringan disebabkan oleh padatan tersuspensi yang mengandung molekul sabun, surfaktan, dan detergen (Kholif dan Ratnawati, 2017). Tingginya konsentrasi TSS dapat menghalangi masuknya cahaya matahari pada suatu perairan, dan dapat menyebabkan tejadinya pendangkalan 
perairan sungai akibat meningkatnya sedimentasi.

Adanya penurunan konsetrasi TSS dan kekeruhan dikarenakan adanya pasir gumuk pada reaktor biosand filter. Pasir gumuk memiliki tekstur tanah yang halus dengan porositas yang tinggi, sehingga pasir gumuk sangat baik untuk dijadikan sebagai bahan untuk menyaring air. Selain itu juga dengan adanya tambahan pasir aktif, karbon aktif, pasir silika, mangase, dan zeolite juga mampu menurunkan kandungan residu tersuspensi (TSS), dan kekeruhan (Dewi, 2013; Fadhillah dan Wahyuni, 2016). Berdasarkan penelitian Hidayah (2019), biosand filter menggunakan media pasir bancar dan media manganese greensand dapat menurunkan konsentrasi residu tersuspensi (TSS) masing - masing sebesar $80 \%$ dan $50 \%$. Oleh karena itu adanya penurunan tingkat kekeruhan dan konsentrasi residu tersuspensi (TSS) membuat warna air menjadi lebih jernih (Gambar 1).

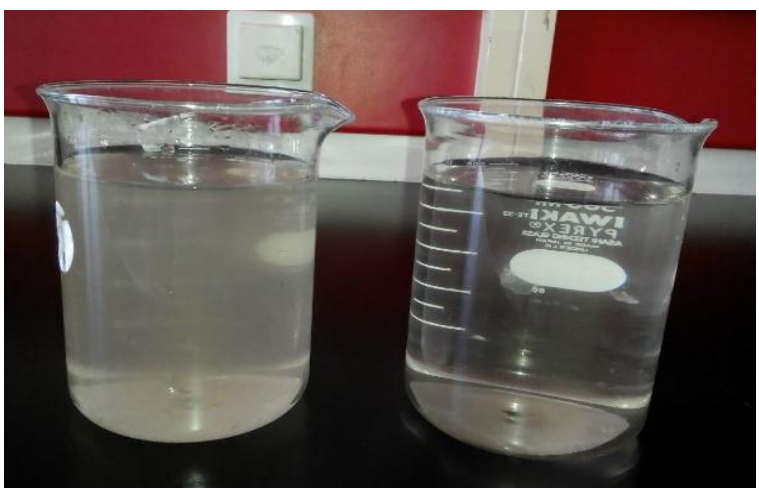

Gambar 2. Warna air Sungai Gadjah Wong Sebelum perlakuan (kiri) dan setelah perlakuan menggunakan modifikasi biosand filter menggunakan pasir gumuk (Kanan)

Berdasarkan hasil pengukuran sampel air Sungai Gadjahwong secara kimia nilai biochemical oxygen demand (BOD) dan chemical oxygen demand (COD) sungai Gadjah Wong tinggi (BOD: $78.1 \mathrm{mg} / \mathrm{L}$; COD: $217 \mathrm{mg} / \mathrm{L})$. Nilai tersebut melebihi nilai baku mutu air kelas I yang telah ditetapkan oleh Pergub DIY nomor 20 tahun 2008 (BOD: 3 $\mathrm{mg} / \mathrm{L}$; COD: $25 \mathrm{mg} / \mathrm{L}$ ) (Tabel 1). Tingginya kandungan BOD dan COD air Sungai Gadjahwong, dikarenakan oleh banyaknya limbah domestik yang dibuang secara langsung ke badan sungai. Ketika dilakukan penyaringan air sungai menggunakan reaktor biosand filter pasir gumuk ternyata nilai BOD dan COD justru menjadi lebih tinggi (BOD: $87.4 \mathrm{mg} / \mathrm{L}$; COD: $317 \mathrm{mg} / \mathrm{L}$ ) dibandingkan sebelum dilakukan perlakuan. Tingginya konsetrasi BOD dan COD setelah proses filtrasi tersebut disebabkan oleh kandungan materi organik yang terdapat pada bak penampungan air sungai. Hal ini dikarenakan pada bak penampungan terdapat eceng gondok Eichhornia crassipes.

Perlakuan modifikasi biosand filter menggunakan pasir gumuk juga dapat menurunkan kandungan klorida air Sungai Gadjah Wong. Sebelum perlakuan air Sungai Gadjah Wong memiliki kandungan klorida sebesar 14,1 $\mathrm{mg} / \mathrm{L}$, setelah perlakuan kandungan klorida turun menjadi $4 \mathrm{mg} / \mathrm{L}$. Diketahui bahwa klorida merupakan senyawa kimia yang bersifat toksik terhadap lingkungan perairan. Senyawa klorida ini akan lebih berbahaya lagi apabila bereaksi dengan senyawa organik lainnya. Berdasarkan nilai baku mutu PP No 82 tahun 2001, kandungan klorida yang diperbolehkan diperairan adalah sebesar $600 \mathrm{mg} / \mathrm{L}$. Selain itu juga pada perlakuan ini dapat menurunkan kandungan detergen di Sungai Gadjah Wong. Kandungan detergen sebelum perlakuan adalah $0,28 \mathrm{mg} / \mathrm{L}$, setelah perlakuan kandungan detergen turun menjadi $0,14 \mathrm{mg} / \mathrm{L}$.

Pengujian sampel air sungai secara biologi dilakukan dengan menghitung nilai total coliform dan jumlah bakteri E. coli. Hasil penelitian menunjukkan bahwa air sungai Gadjahwong memiliki total coliform $\left(15 \times 10^{3}\right.$ MPN/100 mL) dan jumlah bateri $4 \times 10^{3}$ MPN/100 ml) yang melebihi nilai baku mutu air kelas I (Tabel 1). Nilai total coliform dan 
jumlah bakteri $E$. coli yang digunakan sebagai syarat baku mutu air kelas I sesui dengan Pergub DIY nomor 20 tahun 2008 secara berurutan yaitu $1 \times 10^{3}$ dan 0 . Ketika dilakukan penyaringan air sungai menggunakan reaktor biosand filter ternyata jumlah coliform $\left(21 \times 10^{3} \mathrm{MPN} / 100 \mathrm{~mL}\right)$ dan jumlah bakteri $E$. coli $(7 \times 103 \quad \mathrm{MPN} / 100 \mathrm{~mL})$ mengalami kenaikan. Hal ini disebabkan karena pada reaktor biosand filter ini tidak memiliki kemampuan dekontaminasi mikrorganisme seperti jamur, bakteri, protozoa dan virus. Oleh karena itu menyempurnakan biosand filter ini perlu ditambahkan alat seperti reaktor UV light disinfection. Berdasarkan penelitian Endarko et al., (2013) penambahan UV light disinfection pada reaktor biosand filter dapat membunuh bakteri pathogen dan virus dalam air.

\section{KESIMPULAN}

Berdasarkan hasil penelitian pengolahan air sungai Gadjah Wong menggunakan modifikasi biosand filter dengan pasir gumuk dan pasir pantai disimpulkan bahwa 1) Perlakuan biosand filter pasir gumuk dapat menurunkan kandungan residu tersuspensi (TSS), 2) menurunkan tingkat kekeruhan, 3) mampu meningkatkan kandungan DO perairan; 4) secara kimiawi dapat menurunkan kandungan clorida dan detergen dalam perairan Sungai Gadjahwong.

\section{DAFTAR PUSTAKA}

Dewi S Y. 2013. Efektitas Filter Gerabah tanah Liat, Karbon Aktif dan Ekstrak Sirih dalam Pengelolaan Air Baku Skala Rumah Tangga. Fakultas Teknik Universitas Satya Negara Indonesia. Jurnal Lingkungan Tropis. Vol. 5 (2)

Endarko., Putro T., Nuzula N.I., Armawati N., Wardana A., Rubiyanto A., Muntini M.S. 2013. Rancang Bangun Sistem Penjernihan dan Dekontaminasi Air Sungai Berbasis Biosand Filter dan Lampu Ultraviolet. Jurnal Berkala Fisika. Vol. 16 (3) : $75-84$

Fadhilah, M., Wahyuni, D. 2016. Efektifitas penambahan karbon aktif cangkang kelapa sawit (Elaeis guineensis) dalam proses filtrasi air sumur. Jurnal
Kesehatan komunitas. Vol 3 (2): 9398

Hidayah, E. N., Hikmah, S. N., Kamal, M. F. 2019. Efektifitas media filter dalam menurunkan TSS dan Logam Fe pada Air Sumur Gali. Jukung Jurnal Teknik Lingkungan. Vol. 5 (2): $1-8$

Kholif, M.A., Ratnawati, R. 2016. Removal ammonia $\left(\mathrm{NH}_{3}\right)$ di industrial chiken slaughterhouse by anaerobic biofilter. Prosiding seminat internasional the $1^{\text {st }}$ Seminar on Environment and Health Toward SDG'S Achievement 20130 Integration System on Environment and Health Sustainability. Pp. 171 179

Kodoatie, R.J. dan Sjarief, R. 2010. Tata Ruang Air. Yogyakarta: ANDI Yogyakarta

Krisnawati., Widya T.Y., Nurasih A., Santoso A.M. 2015. Perancangan Moolief Bioreactor untuk Remediasi Air Sungai Brantas Kediri Tercemar Limbah Domestik dan Industri. Prosiding Seminar Nasional Pendidikan Biologi 2015.

McGhee, Terence. J and Steel, E. W. 1991. Water Supply and Sewerage, 6th Edition. New York: McGraw - Hill Book Co.

Nurhayati, I., Ratnawati, R., dan Sugito. 2019. Effect of potassium and carbon addition on bacterial algae bioremediation of boezem water, Environmental Engineering Research, 24(3): 495-500.

Samina, Setiani, O., dan Purwanto. 2013. Efektivitas Instalasi Pengolahan Air Limbah (IPAL) Domestik di Kota Cirebon terhadap Penurunan Pencemar Organik dan E-coli. Jurnal Ilmu Lingkungan, 11 (1), pp. 36-42.

Suhartana. 2006. Pemanfaatan tempurung kelapa sebagai bahan baku arang aktif dan aplikasinya untuk penjernihan air sumur di Desa Belor Kecamatan Ngaringan Kabupaten Grobogan. Jurnal berkala fisik. Vol. 9 (3): 154 160

Suripin. 2001. Pelestarian Sumber Daya Tanah dan Air. Penerbit Andi, Yogyakarta. 